\title{
Biochemical and Microbiological Quality Changes of Indian Oil Sardine (Sardinella longiceps) Stored under Flake Ice and Dry Ice
}

\author{
A. Jeyakumari*, L. Narasimha Murthy and S. Visnuvinayagam
}

Mumbai Research Centre of ICAR-CIFT, Vashi, Navi Mumbai, Maharastra, India - 400703

*Corresponding author

\section{A B S T R A C T}

\section{Keywords}

Indian oil sardine, Dry ice, Flake ice, Quality, Shelf life

\section{Article Info}

Accepted:

15 July 2018

Available Online:

10 August 2018
In the present study, quality changes of Indian oil sardine (Sardinella longiceps) stored under dry ice (solid carbon dioxide)/ flake ice and its combination was studied. Fish were stored into three different batches. The first batch was packed with $100 \%$ flake ice (S1), the second batch was packed with dry ice at the level of $50 \%(\mathrm{~S} 2)$ and the third batch was packed with $50 \%$ flake ice and $50 \%$ dry ice (S3). Biochemical quality parameters viz. TVB-N, TMA-N, FFA, PV and TBA content showed an increasing trend and were within the acceptable limit during storage. Mesophilic count reached the maximum limit for acceptability of $7.0 \log _{10}$ on $7^{\text {th }}$ day, $10^{\text {th }}$ day, $14^{\text {th }}$ day for S2, S1, S3 samples respectively. Moreover, psychrophilic and $\mathrm{H}_{2} \mathrm{~S}$ producer counts were found to be lower in S3 samples. Based on the sensory and microbial analysis oil sardine stored under the combination of dry ice and flake ice (S3) had a shelf life up to 14 days than fishes stored in $100 \%$ flake ice (10 days) and $50 \%$ dry ice ( 7 days) alone.

\section{Introduction}

Fish is an excellent source of protein, vitamin and minerals. Moreover, fish lipids have numerous health benefits for human (Elizabeth, 2013). Nearly, 25\% people acquire animal protein from fish and shell fish. Around $35 \%$ of fish is eaten as fresh, chilled or frozen. It is also canned or cured (16\% each) or made into fish meal and oil $(32 \%)$. Indian oil sardine (Sardinella longiceps) is one of the most abundant pelagic species on the west coast of India and it contributes $15-20 \%$ to the total marine fish landings. Normally, consumers prefer the fresh or iced sardines than the frozen or canned one. The freshness of fish is the most important and fundamental criterion for considering the quality of the final product. Due to high moisture content and non protein nitrogen substances fish is more prone to deteriorate than chicken and red meat. The most important methods used for preserving the fish are the application of low temperature. Rapid cooling and upholding of low temperature from catch to consumer are necessary to obtain ideal shelf life of seafood. Shelf life extension of fish and fishery products allows the processors to plan and control their processing and marketing channels as well as transport modes (Madrid and Phillips, 2000). Preservation of fish under 
chilled or iced condition $\left(0-2^{\circ} \mathrm{C}\right)$ reduces or delays the microbial growth and extends the shelf life of fish (Norman and Benjamin, 2000). Recently, preservation of fish under dry ice is gaining popularity in India. Dry ice is a compressed form of the Carbon dioxide $\left(\mathrm{CO}_{2}\right)$, also called as solid $\mathrm{CO}_{2}$. It has a surface temperature of $-78^{\circ} \mathrm{C}$ and it disappears in the environment by sublimation. Owing to its cooling effect and sublimation, most of the airlines are prefer to use the dry ice for shipment of fish/meat and chemicals (FAO, 2011). Recently dry ice is often mixed with flake ice to extend the cooling energy of flake ice, save shipping weight and cost. Several exporters use dry ice in combination with flake ice simply without any technical basis for transportation of fresh fish (Jeyasekaran et $a l ., 2008)$. Few studies have been reported for the extension of shelf life of fish using the dry ice and flake ice combination (LeBlanc and LeBlanc, 1992; Jeyasekaran et al., 2004; Jeyasekaran et al., 2008; Huynh et al., 2007). To the best of our knowledge, there is no report on the quality of sardine under flake ice-dry ice combination. Based on the above information, the present study was aimed to study the individual and combined effect of flake ice and dry ice on the quality and shelf life of sardine fish.

\section{Materials and Methods}

\section{Raw material}

Indian oil sardines (Sardinella longiceps) were procured (weight: 30-35; length: 15$16 \mathrm{~cm}$ ) from fish processing Industry, Taloja (Mumbai) and transported to the laboratory with well- iced condition using insulated ice box (1:1, fish/ice). Dry ice was procured from $\mathrm{CMW} \mathrm{CO}_{2}$ technologies, Mumbai. Flake ice was prepared from lab scale flake ice machine (BANWAY-IRC, New Delhi, India). All chemicals (analytical/general grade) procured from the manufacturers of Merck, India were used for the study.

\section{Sample preparation}

Fresh Indian oil sardines procured from fish processing Industry were used for the study. Fish were stored into three different batches. The first batch was packed with $100 \%$ flake ice (S1), the second batch was packed with dry ice at the level of $50 \%$ (S2) and the third batch was packed with $50 \%$ flake ice and $50 \%$ dry ice (S3). Care was taken to avoid direct contact of fish with dry ice by using wax coated kraft paper. All the insulated ice boxes were kept at room temperature (28 \pm $2^{\circ} \mathrm{C}$ ). The melted ice was drained daily and re-icing was carried out in order to compensate melting. Samples were taken at regular interval periods and analyzed for biochemical, microbiological and sensory analyses.

\section{Biochemical quality analysis}

Moisture, protein, fat and ash content of fish was analyzed by the method of AOAC (2005). pH of homogenized fish samples were determined by a calibrated glass electrode $\mathrm{pH}$ meter (Cyberscan 510; Eutech Instruments, Singapore). Total volatile base nitrogen (TVB-N) and trimethylamine nitrogen (TMA$\mathrm{N})$ contents in fish meat were measured according to Conway micro- diffusion method (Conway 1950). Free fatty acid (FFA) and Peroxide value were analyzed by the method of AOAC (2005) method. Thiobarbituric acid (TBA) value was determined as described by Tarladgis et al., (1960).

\section{Sensory evaluation}

Sensory evaluation of fish samples (cooked) were performed by a six trained panelist of fish processing division in the Mumbai research center of CIFT and sensory score were made according to Meilgaard et al., (1999). The sensory attributes viz. appearance, color, flavor, taste and overall acceptability were evaluated. The sensory 
score below 5 was considered unfit for human consumption.

\section{Microbiological analysis}

\section{Mesophilic and psychrophilic count}

Fish sample was aseptically weighed and blended with $0.1 \%$ peptone in a stomacher (Seaward, UK) for $2 \mathrm{~min}$. The blended material was serially diluted up to $10^{-6}$ dilution; then, $0.5 \mathrm{ml}$ of sample was transferred into Tryptone Glucose Beef Extract (TGBE) agar (Hi Media, \#M791) plates and spread over the surface. Mesophilic count was determined after 2 days incubation at $35^{\circ} \mathrm{C}$. Psychrophilic count was determined after 7 days incubation at $7^{\circ} \mathrm{C}$ (Downes and Ito, 2001).

\section{$\mathrm{H}_{2} \mathrm{~S}$ producing bacteria}

$\mathrm{H}_{2} \mathrm{~S}$ producing bacteria were enumerated according to Koneman et al., (1992) with slight modification. Peptone Iron agar (PIA) (\#M440, Hi-Media:) supplemented with 1.5 $\mathrm{ml}$ of $2 \%$ Ferrous ammonium sulfate (FAS) and $4 \mathrm{ml}$ of $1 \%$ L-Cystine hydrochloride were used for the enumeration of $\mathrm{H}_{2} \mathrm{~S}$ forming bacteria. Black color colonies are considered as $\mathrm{H}_{2} \mathrm{~S}$ producing bacteria after incubation of plates for 5 days at $20^{\circ} \mathrm{C}$.

\section{Results and Discussion}

\section{Biochemical composition of Indian oil sardine}

Fresh oil sardine meat had $70.45 \%$ moisture and $19.78 \%$ protein. Ravichandran et al., (2011) observed similar results for oil sardine. Fat or lipids present in the fish meat contribute to the taste and texture of fish. In the present study, oil sardine showed $8.43 \%$ fat which indicates it falls under the high-fat content category. Oil sardine used in the study had $1.5 \%$ ash which indicates that oil sardine rich in minerals and trace elements. The proximate composition of fish muscle is influenced by many factors viz. species, age, season and feed etc. (Karakoltsidis et al., 1995).

\section{Changes in pH}

Fresh sardine meat had a $\mathrm{pH}$ of 6.5. According to Huss (1995), the post mortem $\mathrm{pH}$ for most of fish is 7 or slightly lower than 7. It was observed that $\mathrm{pH}$ showed an increased trend during storage (Fig. 1a). The increase in $\mathrm{pH}$ may be due to accumulation of basic compounds, mainly by the bacterial action (Binsi et al., 2014). However, the rate of increase was less in S2 and S3 sample. Results are in agreement with previous reports on fish stored under $\mathrm{CO}_{2}$ enriched environment (De la Hoz et al., 2000).

\section{Changes in TVB-N and TMA-N}

TVB-N and TMA-N content determination used as quality indicator of fish and shellfish stored in ice. Initial TVB-N of fresh sardine was $6.7 \mathrm{mg} \%$ and it showed increased trend during storage (Fig. 1b). The increase in TVB-N may be due to degradation of protein and non-protein nitrogenous compounds by microbial activity. Among three treatment, S3 had a lower TVB-N value (6.7-23.8mg\%). Sasi et al., (2003) observed similar results for sardine stored in $20 \%$ dry ice along with $50 \%$ flake ice. The TVB-N value $>40 \mathrm{mg} \mathrm{N} / 100 \mathrm{~g}$ is considered as rejection limit for fish and shellfish (Mendes, 2005). Initial TMA-N content in fish meat was $1.2 \mathrm{mg} \%$ which was increased gradually in all the samples during storage (Fig. 1c). The accumulation of TMA$\mathrm{N}$ content in fish may varies from species to species due depends on trimethylamine-oxide content in fish (Huss, 1988; Oehlenschlager, 2002). The level of $10-15 \mathrm{mg}$ TMA-N /100g is recommended for human consumption (Connell, 1995). Accordingly, all sample had TMA-N content within the acceptable limit during storage. 

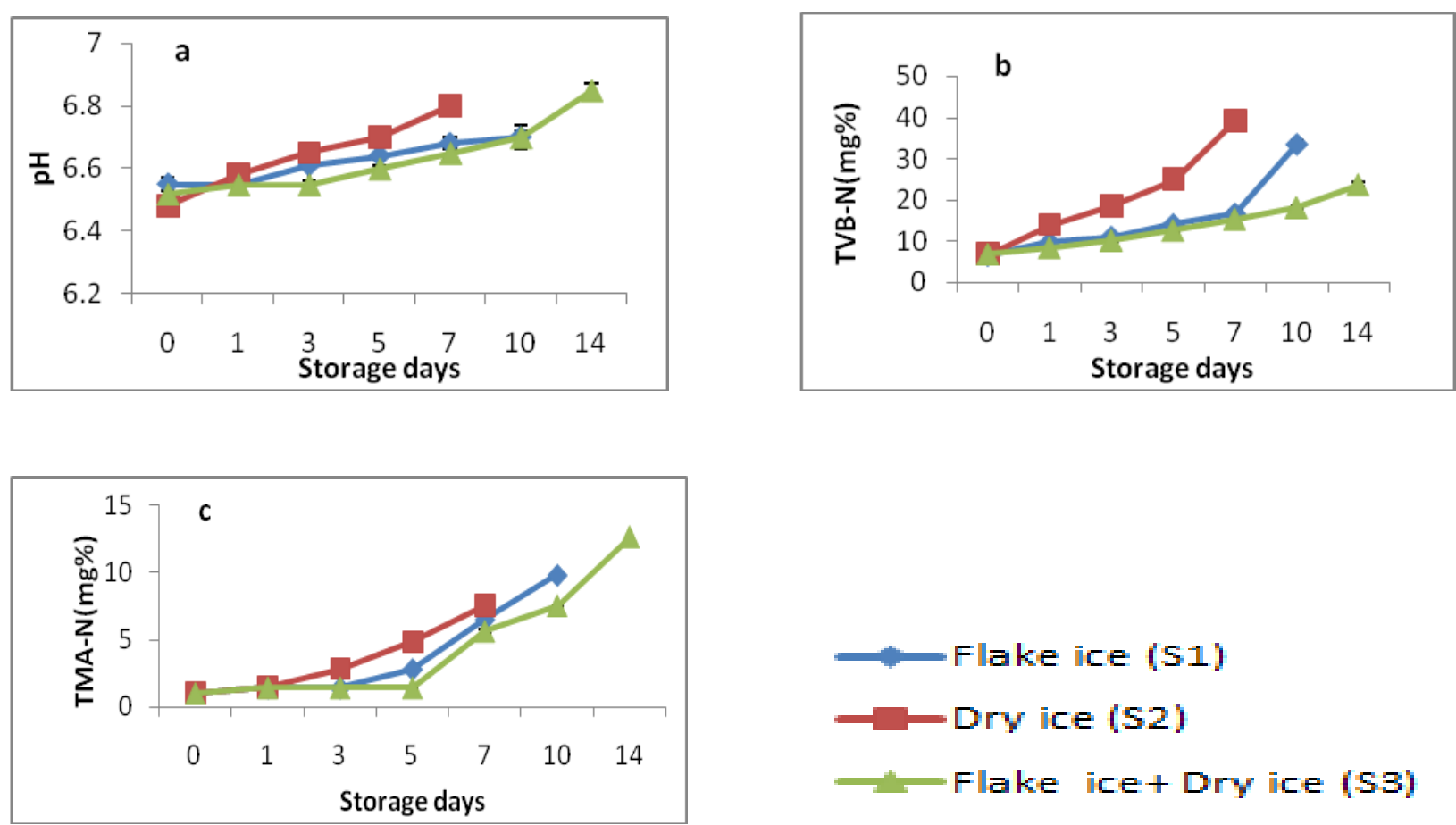

Fig.1 Changes in a) pH, b) TVB-N and c) TMA-N values of sardine during ice storage
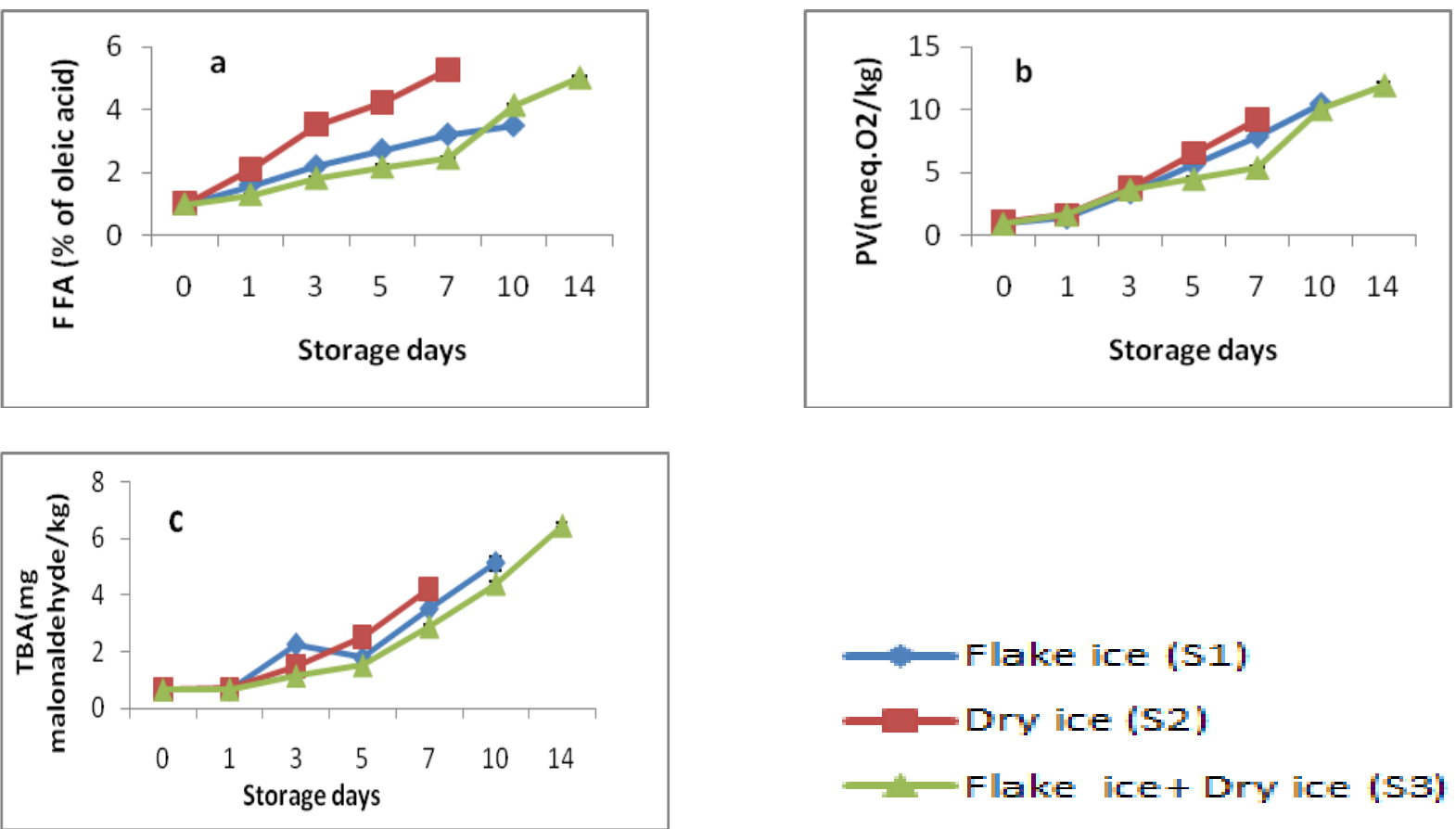
Fig.2 Changes in a) FFA, b) PV and c) TBA values of sardine during ice storage



Fig.3 Changes in over all acceptability of sardine during ice storage
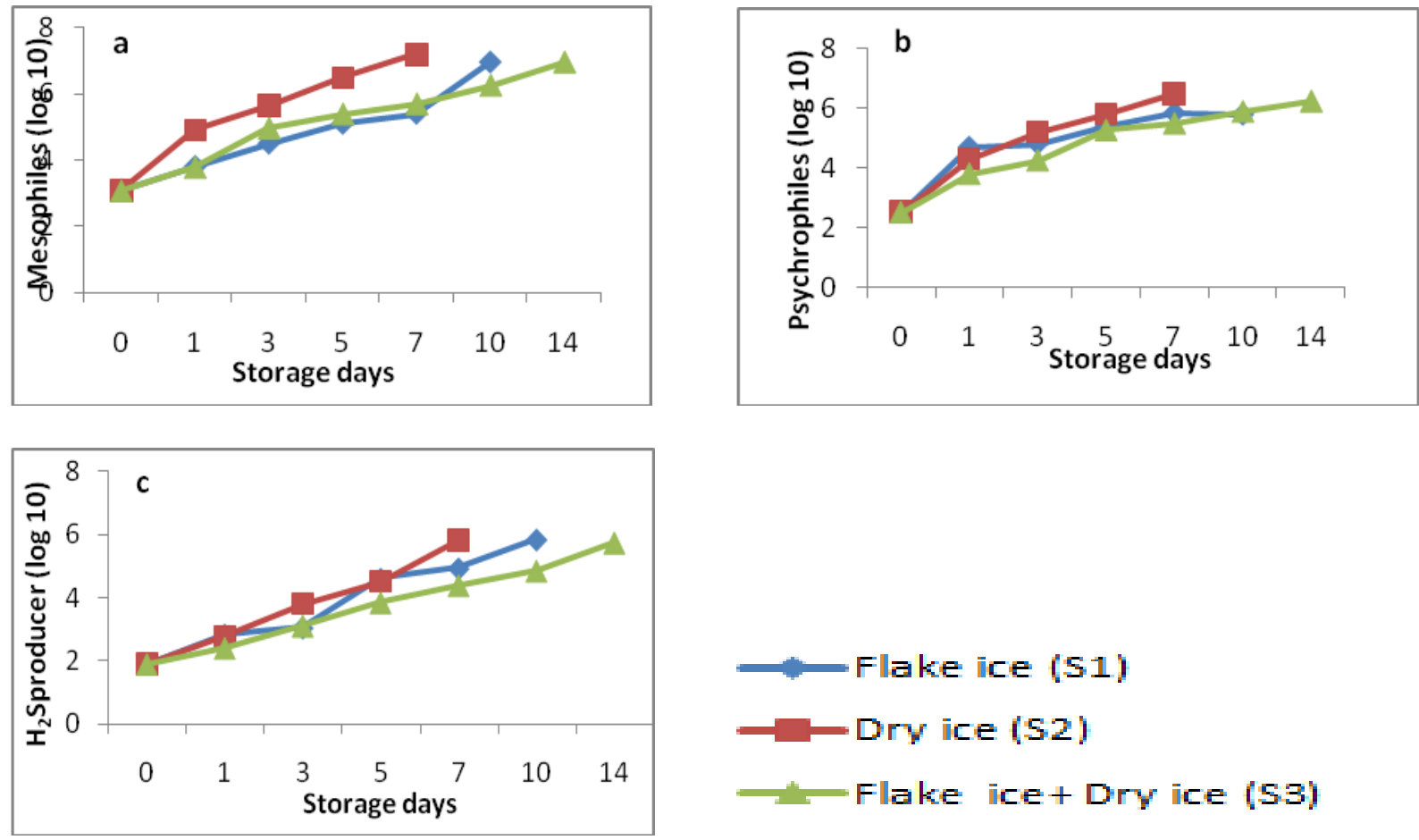

Fig.4 Changes in a) Mesophiles, b) Psychrophiles and c) $\mathrm{H}_{2} \mathrm{~S}$ producer count of sardine during ice storage

\section{Changes in FFA, PV, TBA}

Fresh sardine had a free acid content of $0.98 \%$ as oleic acid and it showed increased trend during storage (Fig. 2a). The progressive increase in the FFA values over the storage time showed the progressive breakdown of lipids in fish muscle with time in ice. It may be due to enzymatic action takes place in fish during iced storage (Aidos et al., 2003). The TBA and peroxide value are used to measure the lipid oxidation products. PV measures the 
primary lipid oxidation products and play a major role in formation of aldehydes and other secondary oxidation products. Fresh sardine fish meat had PV of $0.95 \mathrm{meqO}_{2} / \mathrm{kg}$ and it showed an increased trend in all samples during storage (Fig. 2b). However, all the samples had an acceptable level of PV values $\left(20 \mathrm{meqO}_{2} / \mathrm{kg}\right)$ under ice storage.

TBA value measures the formation of malonaldehyde, a secondary lipid oxidation product due to oxidation of polyunsaturared fatty acids (Benjakul et al., 2005). Unlike PV, thiobarbituric acid values were also showed an increased trend during storage. A TBA value of $1-2 \mathrm{mg}$ of $\mathrm{MDA} / \mathrm{kg}$ is generally considered as the limit for acceptability of fish. However, fish can be consumed up to 5 $\mathrm{mg}$ malonaldehyde/kg of TBA value (Connell, 1995; Adenike, 2014). Accordingly, S3 crossed an acceptable limit of TBA values $(6.45 \mathrm{mg}$ malonaldehyde/ $\mathrm{kg})$ up to $14^{\text {th }}$ day (Fig. 2c). Even though S1 and S2 samples showed an acceptable limit of TBA values during storage, due to off odor it was rejected on the $10^{\text {th }}$ day, $7^{\text {th }}$ day respectively.

\section{Changes in overall acceptability}

Fresh sardine had bright natural color, seaweed odor and firm characteristics. The overall acceptability of Indian oil sardine during ice storage is depicted in Figure 3. It was noticed that there is significant $(p<0.05)$ difference in the overall acceptability of sardine during storage due to loss of characteristics odor and appearance.The overall acceptability of S1 samples reached below 5 on $10^{\text {th }}$ day.

In the case of S2 samples, slight off- flavor was observed on the $5^{\text {th }}$ day and thereafter the score of overall acceptability reached 4.0 on $7^{\text {th }}$ day. It may be due to the development of off-flavor. Moreover, S3 sample had a shelf life up to the $14^{\text {th }}$ day. Results are in agreement with previous reports for shrimp stored under dry ice and flake ice (Sasi et al., 2003).

\section{Changes in microbiological quality}

Fresh sardine meat had a mesophilic count of $3.1 \log _{10}$, which was slowly increased during storage (Fig. 4a) and reached maximum limit for acceptability of $7.0 \log _{10}$ (ICMSF, 1998) on $7^{\text {th }}$ day, $10^{\text {th }}$ day, $14^{\text {th }}$ day for S2, S1, S3 samples, respectively. Jeyasekaran et al., (2008) observed similar results for fish stored under dry ice and its combination with flake ice. Bao et al., (2007) also found shelf life extension of fishes stored under dry ice. Unlike mesophiles, psychrophilic, counts were also showed an increased trend during storage (Fig. 4b). Moreover, psychrophilic counts are less in S2 and S3 sample. Results indicated that fish stored under dry ice inhibited the psychrophilic growth. Jeyasekaran et al., (2004) also observed similar results for grouper stored under dry ice and flake ice combination. $\mathrm{H}_{2} \mathrm{~S}$ forming bacteria are classified as spoilage bacteria and it is responsible for the spoilage of fish and shellfish under chill storage condition. Results showed a gradual increase $\mathrm{H}_{2} \mathrm{~S}$ producer during storage (Fig. 4c). Moreover, $\mathrm{H}_{2} \mathrm{~S}$ producers count was lower in S2 and S3 sample than mesophiles. Results indicated that inhibitory effect of $\mathrm{CO}_{2}$ reduced the $\mathrm{H}_{2} \mathrm{~S}$ producing bacteria and its population. Sasi et al., (2003) also observed similar results for seer fish stored in flake ice and dry ice.

It can be concluded that oil sardine stored under flake ice and dry ice combination (S3) had an acceptability of 14 days than the sample stored only in flake (10 days). Moreover, fish stored only in dry ice (S2) had acceptability only up to $7^{\text {th }}$ day. Further, it was observed that the quality of sardine was found to be good in flake ice and dry ice combination than dry ice or flake ice alone. Results suggested that application of only dry ice for preservation of fish will be costly and 
also higher concentration of dry ice is needed, while dry ice and flake ice mixture at the ratio of 50\%:50\% found to be effective and it may be utilized for short- term transportation of sardine under chilled condition.

\section{Acknowledgments}

The authors thank the Director, ICAR-CIFT, Cochin for providing necessary facilities to carry out this study and the technical assistance rendered by all staffs of Mumbai research Centre of ICAR-CIFT are greatly acknowledged.

\section{References}

AOAC. 2005. Official methods of analysis of AOAC International. $17^{\text {th }}$ edn. Association of Official and Analytical Chemists International, Washington, DC.

Adenike, O.M. 2014. The Effect of Different Processing Methods on the Nutritional Quality and Microbiological Status of Cat Fish (Clarias lezera). J. Food Process. Technol. doi.org/10.4172/ 2157-7110.1000333

Aidos, I., Van Der Padt, A., Boom, R.M. and Luten, J.B. 2003. Quality of crude fish oil extracted from herring by products of varying states of freshness. J. Food Sci., 68: 458-465.

Bao, H. N. D., Sigurjon, A. and Kristin Anna. I.O. 2007. Effects of Dry Ice and Superchilling on Quality and Shelf Life of Arctic Charr (Salvelinus alpinus) Fillets. Int. J. Food Engg., 3 (3): 1 - 27.

Benjakul, S., Visessanguan, W. and Tanaka. M. 2005. Properties of phenoloxidase isolated from the cephalothorax of kuruma prawn (Penaeus japonicus). $J$ Food Biochem. 29: 470-485.

Binsi, P.K., George Ninan, Zynudheen, A.A., Neethu, R., Venkateshwarlu Ronda and Ravishankar, C.N. 2014. Compositional and chill storage characteristics of microwave blanched sutchi catfish (Pangasianodon hypophthalmus) fillets. Int. J. Food sci. Technol., 49: 364-372.

Connell, J.J. 1995. Quality deterioration and extrinsic quality defects in raw material. In: Control of fish quality. $4^{\text {th }}$ edn. Fishing News Books Ltd. Survey, England. 241.

Conway, E.J. 1950. Micro-diffusion analysis and volumetric error. $5^{\text {th }}$ edn. Lockwood and Son Ltd, London. 467-472.

De la hoz, L., Lopez-Galvez, D.E., Fernandez, M., Hierro, E. and Ordonez. K.A. 2000. Use of carbon di-oixided enriched atmospheres in refrigerated storage $\left(2^{\circ} \mathrm{C}\right)$ of salmon (Salmo salar) streaks. Eur. Food Res. Technol., 210: $179-188$.

Downes F. P. and ITO, K. (Eds.). 2001. Compendium of Methods For the Microbiological Examination of Foods, 4th Ed., APHA, Washington, D.C.

Elizabeth, K.L. 2013. Health benefits of seafood; Is it just the fatty acids? Food chem., 140: 413- 420.

FAO. Transportation of fish and fish products Fisheries and aquaculture department, Rome. Updated 27 May 2005.Retrieved 18 March 2011. http://www.fao.org/fishery/topic/12327/

Huynh, N. D., Sigurjon, A. and Kristin Anna, I.O. 2007. Effects of Dry Ice and Superchilling on Quality and Shelf Life of Arctic Charr (Salvelinus alpinus) Fillets, Int. J. Food Engg., 3(3): 1 - 27.

Huss, H. H. 1995. Fresh fish; Quality and quality changes. FAO Fisheries Series, $\mathrm{Nr} 29$, Italy, 132

ICMSF. 1998. International Commission on Microbiological Specifications for Foods, Micro-organisms in Foods, 6. Microbial ecology of food commodities. Baltimore: Blackie Academic \& Professional.

Jeyasekaran, G., Anandaraj, R., Ganesan, P. 
Jeya Shakila, R. and Sukumar, D. 2008. Microbial and biochemical quality of grouper (Epinephelus chlorostigma) stored in dry ice and water ice. Int. J. Food sci. Technol., 43: 145 - 153.

Jeyasekaran, G., Ganesan, P., Jeyashakila, R., Maheswari, K. and Sukumar. D. 2004. Dry ice as a novel chilling medium along with water ice for short-term preservation of fish Emperor breams, lethrinus (Lethrinus miniatus). Innov. Food Sci. Emerg. Technol. 5(4): 485493.

Karakoltsidis, P.A., Zotos, A. and Constantinides. $\quad$ S.M. 1995. Composition of the Commercially Important Mediterranean Finfish, Crustaceans and Molluscs. $J$ Food Compost. Anal., 8: 258-273.

Koneman, E. W., Allen, S. D., Janda, W. M., Schreckenberger, P. C. and Winn. W.C. J. 1992. Colour Atlas and Textbook of Diagnostic Microbiology, 4th Ed, J. B. Lippincott Company, Philadelphia.

Leblanc, R. J. and Leblanc. E. L. 1992. Effect of superchilling with $\mathrm{CO}_{2}$ snow on the quality of commercially processed cod (Gadus morhua) and winter flounder (Psedopleuronectes americanus) fillets. In: Huss, H. H., Jakobsen, M. and Liston, J. (Eds.). Quality Assurance in the Fish Industry. Elsevier Science Publishers B. V. All rights reserved. Pp. 115-124.

Madrid, R.M.M. and Phillips. H. 2000. Post Harvest Handling and Processing. In : Fresh water prawn culture, the farming of Macrobrachium rosenbergii
(M.B.New and W.C.Valent, eds) pp. 326-344,Onsey Med, Oxford, U.K.

Meilgaard, M., Civille G. V. and Carr. B.T. 1999. Sensory evaluation techniques (3rd ed.). Boca Raton, Fla: CRC Press. p. 387

Mendes, R., Goncalves, Pestana, A. and Pestana, C. 2005. Indole production and deepwater pink shrimp (Parapenaeus longirostris) decomposition. $J$ Eur. Food Res. Tech., 214: 125-130.

Norman, F.H. and Benjamin, K.S. 2000 Seafood Enzymes Utilization and Influence on Postharvest Seafood Quality. Marcel Dekker, Inc., New York.

Oehlenschlager, J. 2002. Influences of different pre-storage treatments on resulting shelf life of ice-stored Barentsseacod. J. Aquat. Food prodt. Technol., 11: $187-200$

Ravichandran, S., Kumaravel, K. and Florence. P.E. 2011. Nutritive Composition of some Edible Fin Fishes. Int. J. Zoological Res. 7: 241-251.

Sasi, M., Jeyasekaran, G., Shanmugam S.A. and Jeyashakila. R. 2003. Evaluation of the Quality of Seer Fish (Scomberomorus commersonii) Stored in Dry Ice (Solid Carbon Dioxide). $J$. Aquat. Food Prodt. Technol., 12 (2): 61 -72 .

Tarladgis, G. B., Watts, M. B. and Younathan. T. M. A. 1960. Distillation method for the quantitative determination of malonaldehyde in rancid foods. J. Am. Oil Chem. Soci., 37:

\section{How to cite this article:}

Jeyakumari, A., L. Narasimha Murthy and Visnuvinayagam, S. 2018. Biochemical and Microbiological Quality Changes of Indian Oil Sardine (Sardinella longiceps) Stored under Flake Ice and Dry Ice. Int.J.Curr.Microbiol.App.Sci. 7(08): 2758-2765. doi: https://doi.org/10.20546/ijcmas.2018.708.289 